\title{
Antifungal action of Lippia alba essential oil in Rhizoctonia solani disease management
}

\author{
Arvind Saroj ${ }^{1,4} \cdot$ C. S. Chanotiya ${ }^{2,3}$ (1) $\cdot$ Ranjana Maurya $^{2,3} \cdot$ V. S. Pragadheesh ${ }^{2} \cdot$ Anju Yadav $^{2} \cdot$ A. Samad ${ }^{1,3}$
}

(C) Springer Nature Switzerland AG 2019

\begin{abstract}
Plant pathogens damage agriculture sector to a large extent, resulted in poor crop yield and quality. A well followed practice to curb plant diseases are mostly involved with application of conventional fungicides (synthetic chemical). However, their continuous and uncontrolled use has emerged as big challenge for humans due to the hazardous effect to the environment. This can also leads to the development of resistance to plant pathogens. Green chemistry based approaches have revolutionized the development of new strategies to curb plant diseases. Natural products mainly essential oils have potential to minimize the use of synthetic fungicides for some extent. Therefore, current study was conducted to find out alternative of disease managements strategies against Rhizoctonia solani damping off. The rationale was to study the effect of linalool rich Lippia essential oil against two $R$. solani isolates infecting commercially important crops, Ocimum basilicum and Plantago ovata. Current study revealed that the use of essential oil emulsion can enhance the survivability of seedlings up to $98 \%$ and $92 \%$ in treated $O$. basilicum and $P$. ovata pots as comparison to non-treated pots $20 \%$ and $15 \%$, respectively. Headspace-gas chromatography of treated soil samples have detected minimum oil components leading to lower exposures. Herein, we demonstrated a successful management of damping off disease on two commercially important crops for two consecutive years at nurseries. The isolates of $R$. solani were further characterized up to sub group level for the first time. In conclusion, Lippia essential oil could be used as biopesticide to treat damping of disease at nursery level.
\end{abstract}

Keywords Rhizoctonia solani $\cdot$ Lippia alba $\cdot$ Ocimum basilicum · Plantago ovata . Disease management $\cdot$ Headspace-gas chromatography

\section{Introduction}

Since ancient time, pathogens were reported as potential threats to plants and crops. Almost $12 \%$ reduction in world crop production is reported to be due to pre- and postharvest fungal diseases in developing countries [1]. It has been reported that phytopathogens like $R$. solani, Botrytis cinerea, Fusarium oxysporum, Colletotrichum capsici, Sclerotinia sclerotiorum, Aspergillus spp. and Fusarium solani reduce the self-life and market values of the food commodities. Further, mycotoxins are other threats to the human health, in particular, populations in developing countries [2]. In India, Medicinal and Aromatic Plants (MAPs) have been reported with severe pathogenic infections, in recent times.

Many soil borne Basidiomycetes such as Rhizoctonia solani Kühn (telomorph: Thanatephorus cucumeris) is reported to cause various diseases on vegetables, fruits, staple crops and ornamental plants [3]. The morphological [4] and molecular systematic [5] of $R$. solani has

$\triangle$ C. S.Chanotiya, cs.chanotiya@cimap.res.in; chanotiya@gmail.com; $₫$ A.Samad, samad_cimap@yahoo.co.in | ${ }^{1}$ Department of Plant Pathology, CSIR-Central Institute of Medicinal and Aromatic Plants (CIMAP), Lucknow 226 015, India. ${ }^{2}$ Laboratory of Aromatic Plants and Chiral Separation, CSIR-Central Institute of Medicinal and Aromatic Plants (CIMAP), Lucknow 226015 , India. ${ }^{3}$ Academy of Scientific and Innovative Research, CSIR-Central Institute of Medicinal and Aromatic Plants (CIMAP), Lucknow 226015 , India. ${ }^{4}$ Present Address: Department of Horticulture, Molecular Plant Breeding, North East Agriculture University, Harbin, China. 
been reported. Some peculiar features like branching at right-angle, presence of dolipore septum, constriction at the branch point and septation in the branch hypha are the major characteristics. More often, chains of inflated hyphae known as monolid cells have also been used [4]. Nonetheless, sexual stages are always difficult to be observed in the field or laboratory. Therefore, the broad vegetative criteria for characterization have been resulted into paraphyletic taxonomy, where distinct fungi being clubbed and grouped together. However, the number of nuclei per cells is taken as morphological distinctive character in Rhizoctonia classification [4].

Around nineteenth century, Bordeaux mixture as first chemical fungicide was used to treat pathogen causing downy mildew of grapes. Since then, many conventional fungicides were developed in order to minimize substantial crops damage. As a result, excessive use of conventional fungicides has completely changed the scenario by now. Moreover, uncontrolled use of these chemicals for many decades resulted into several adverse effects to the environment, soil fertility and human health. This also leads into the development of resistant and more destructive plant pathogens. Therefore, demand and necessity of eco-friendly and biopesticides is the foremost need of modern agriculture.

Biopesticides are derived from natural materials like plants and microorganisms. For example, L-carvone, citronellol, p-menthane-3,8-diol, verbenone (terpenoids class) and methyl eugenol (phenylpropanoid class) are considered biopesticides. There are 299 registered biopesticide active ingredients and 1401 active biopesticide product registrations were registered in The United States Environmental Protection Agency (https://www.epa.gov/ ingredients-used-pesticide-products/biopesticide-activ e-ingredients). Essential oils are well documented as natural biopesticides and also proven their effectiveness against various plant pathogens [6-9]. Prior work showed presence of linalool [10] and monoterpene aldehydes [11] in L. alba essential oils. Earlier studies revealed that L. alba essential oil has antimicrobial activity and can be used to manage plant diseases [12]. The study of lippia EO and its main component (limonene and citral) on rat smooth muscle cells revealed its low toxicity and have no influence on physiology of the tissues [13]. The severity and loss due to damping off caused by $R$. solani is well documented by many authors [1]. However, previous studies of L. alba essential oil were not carried out to check its activity in nurseries against any phytopathogen. Although some authors have identified some thymol and carvacrol essential oils and its components which reduced growth of $R$. solani at nursery level $[14,15]$. There is limited research on the use of essential oil and delivery system/its way of use for the management of Rhizoctonia damping-off disease.
Other eco-friendly management option is biological control like stem canker of potato caused by Rhizoctonia solani was successfully managed using PGPRs [16]. The objectives of present communication were following (1) isolation and characterization of Rhizoctonia solani damping off of Ocimum basilicum and Plantago ovata, (2) in vitro antifungal activity of $L$. alba essential oil, and (3) to evaluate Lippia essential oil as biopesticides in nurseries.

\section{Materials and methods}

\subsection{Isolation and characterization of Rhizoctonia solani}

Medicinal and aromatic plants like $O$. basilicum and $P$. ovata were observed with peculiar damping off symptoms in year 2011-2012. Plant pathogens were isolated from the diseased plants, individually. The infected plant parts were cut into small pieces; surface sterilized with $1 \%$ sodium hypochlorite, rinsed thrice with sterile distilled water and placed onto the Potato Dextrose Agar (PDA) plates. The plates were incubated at $25 \pm 2{ }^{\circ} \mathrm{C}$ for 3 days [17]. The isolation yielded fungal colony from all plant samples. The colonies were differing from each other on the basis of their cultural characteristics and named as Oci Rh-1 and PI Rh-1, respectively isolated from $O$. basilicum and $P$. ovata. Both isolates were initially brown that later turned into dark brown to tan brown. To check the number of nuclei per cell, mycelium were stained by $0.5 \%$ aniline blue in lactophenol after treating with $3 \% \mathrm{KOH}$ [8] and examined under bright field optics at $40 \times$.

Anastomosis grouping of the fungus was determined by anastomosis reaction according to Hyakumachi [18]. Agar discs (5 $\mathrm{mm}$ in diameter) cut from the periphery of 2-3 day old cultures of isolate on PDA were placed on sterilized glass slides coated with a very thin layer of $2 \%$ water agar. These discs were paired with tester strains of $R$. solani, AG-1 through AG-10. Slides were incubated at $25^{\circ} \mathrm{C}$ in the dark. When the hyphae from the two discs were overlapping after 48 -h, they were stained with $0.5 \%$ aniline blue in lactophenol and examined microscopically to determine anastomosis reactions. Reactions were placed into one of four categories reported by Carling [19, 20].

The identity of both the fungal isolates was confirmed on molecular basis by analyzing rDNA internal transcribed spacer regions. The fungal culture was grown on PDA for 14 days at $27 \pm 2{ }^{\circ} \mathrm{C}$ and were scraped with a sterile spatula and crushed with the help of liquid nitrogen. DNA extraction procedure accorded to the instructions which was given in the kit user's manual DNeasy Plant Mini Kit (Qiagen/NucleoSpin DNA extraction Kit Macherey- Nagel, Düren, Germany). The extracted DNA pellet 
was kept at $-20^{\circ} \mathrm{C}$. Two primers [ITS-1 (TCCGTAGGTGAA CCTGCGG) (Qiagen) and ITS-4 TCCTCCGCTTATTGATATGC) (Qiagen)] were used for the PCR amplification of the DNA region encoding $18 \mathrm{~S}$, ITS-1, 5.8S, ITS-2 and 28S rDNA [17]. Amplification was carried out in a $25 \mu \mathrm{l}$ PCR reaction mixture containing $2.5 \mu \mathrm{l}$ Taq buffer, $1 \mu \mathrm{l} \mathrm{dNTP,} 0.8 \mu \mathrm{l}$ primers IST1-forward and ITS4-reverse, $3 \mu$ fungal genomic DNA, $0.5 \mu \mathrm{l} \mathrm{Taq}$ DNA polymerase and $16.4 \mu \mathrm{l}$ mili-q water. The PCR setting were: an initial denaturation at $94^{\circ} \mathrm{C}$ for $5 \mathrm{~min}$ followed by 30 cycles of $94^{\circ} \mathrm{C}$ for $1 \mathrm{~min}, 50^{\circ} \mathrm{C}$ for $2 \mathrm{~min}$, and $72{ }^{\circ} \mathrm{C}$ for $3 \mathrm{~min}$, and a final extension at $72^{\circ} \mathrm{C}$ for $7 \mathrm{~min}$. The PCR product was electrophoresed in a $1.2 \%$ agarose gel along with $\lambda$ DNA ladder marker (Invitrogen, Barcelona, Spain) and visualized under UV light. The amplified product was cloned in pGEM-T vector (Promega) as per manufacturer instructions. The selection of right insert with correct orientation was done via restriction enzyme EcoRI giving amplicons of approximately $700 \mathrm{bp}$. The sample was sequenced at CSIR-CIMAP with $A B I$ sequencer model 3730 (PerkinElmer) using the universal primers.

Pathogenicity test of each isolates (Oci Rh-1 and PI Rh-1) was carried out on their respective host plants in separate experiments to confirm Koch's postulate. The inoculum of the fungus was prepared on sterile maize seeds in Erlenmeyer flask by inoculating seeds with 3 discs $(1 \mathrm{~mm})$ of 7 days old culture and kept at $27 \pm 2{ }^{\circ} \mathrm{C}$ for 14 days in dark condition [17]. The healthy, 7-10 days old plants were inoculated with 5 artificially infested maize seeds per pot. Non-inoculated plants served as control. Both inoculated and non-inoculated plants were kept at $28 \pm 2{ }^{\circ} \mathrm{C}$ under $95 \%$ humidity for 3 days and thereafter, placed in the glasshouse at $28 \pm 2{ }^{\circ} \mathrm{C}$ for the development of disease symptoms.

\subsection{Plant materials and isolation of essential oil (EO)}

Lippia alba (syn. L. javanica) leaves were collected for three consecutive years (2013-2015) from the experimental farm of CSIR-CIMAP, Lucknow (voucher specimen no. 12909). The fresh leaves from each year's collection were washed with water and hydrodistilled using a Clevengertype apparatus for $4 \mathrm{~h}$. The collected oil was dried over anhydrous $\mathrm{Na}_{2} \mathrm{SO}_{4}$ and stored at $4{ }^{\circ} \mathrm{C}$ prior to analysis. The yield of the essential oil was $0.6 \%$ (fresh wt basis).

\subsection{GC and GC/MS of essential oil and isolation of linalool}

Gas chromatography coupled with either flame ionization detection or mass spectrometry has been carried out as per authors reported methods [8]. Essential oil was subjected to fractionation/column chromatography using
230-400 mesh silica gel (Merck). Column fractions (vol. of $10 \mathrm{ml}$ each) eluted in 3-5\% ethyl acetate in hexane were further subjected to GC-FID analysis. Fractions with $>95 \%$ sample purity were pooled and chosen for biological activity studies after evaporating the solvents completely using rotary evaporator (BÜCHI make).

\subsection{Nuclear magnetic resonance spectroscopy of isolated compounds}

NMR measurements (both 1D and 2D) were recorded on a Bruker AVANCE III HD spectrometer (Bruker BioSpin GmbH, Germany; $500 \mathrm{MHz}(B O=14 \mathrm{~T})$. The structures were confirmed using Heteronuclear Single Quantum Coherence Spectroscopy and Heteronuclear Multiple Bond Correlation experiments. The deprotonated column fraction \#80 and \#90 eluted in 70-80\% ethyl acetate: hexane (30 $\mu \mathrm{l}$ each) were dissolved in $\mathrm{CDCl}_{3}(700 \mu \mathrm{l})$ directly in $5 \mathrm{~mm}$ NMR tube, to solubilize component completely. Chemical shifts were reported in ppm units. NMR solvent $\left(\mathrm{CDCl}_{3}\right)$ set to $7.26\left({ }^{1} \mathrm{H}\right.$ NMR) and $77.0\left({ }^{13} \mathrm{C}\right.$ NMR). Signal multiplicities were denoted as: $s$, singlet; $d$, doublet; $t$, triplet; $q$, quartet; $\mathrm{m}$, multiplet etc.). Based on 1D and 2D-NMR experiments, column fractions \#80 and \#90 were characterized as $(Z, Z)$ and $(E, E)$-2,6-dimethyl-3,5,7-octatrien-2-ol, respectively.

\subsection{Diffusion assay (volatile phase)}

Fifteen $\mathrm{ml}$ PDA was poured in $90 \mathrm{~mm}$ glass Petri-plate. A $5 \mathrm{~mm}$ disc of 5 days old culture of each $R$. solani isolate was placed in the centre of PDA plate, separately. Thereafter, known amounts $(2,5,10$, and $15 \mu \mathrm{l})$ of essential oil and pure linalool in separate Petri-plate was introduced onto the inner side of each Petri-plate cover/lid and sealed by parafilm immediately. Plates were incubated at $25 \pm 1^{\circ} \mathrm{C}$. Fungal growth was monitored and measured at an interval of 24-h up to 3 days as described earlier [6, 8, 21]. Experiments were repeated twice in triplicates. To analyze the inner environment of the Petri-plate during volatile assay, the headspace of each Petri-plate containing essential oil was studied through solid-phase microextraction technique coupled with GC i.e., SPME-GC-FID [6].

\subsection{Poison food technique (PFT)}

Antifungal activity through contact phase was determined by poisoned food technique (PFT) $[22,23]$. The agar plates were prepared by adding different concentrations $(0.5,1.0$, $1.5,2.0$ and $3 \mu \mathrm{l} / \mathrm{ml}$ ) of essential oil and linalool separately into the PDA at $40-45^{\circ} \mathrm{C}$. In order to ensure proper mixing of oil with media, $0.1 \%$ Tween- 80 was used [8]. R. solani isolates were placed on the PDA plates as per diffusion assay method. Thereafter, all Petri-plates were incubated 
at $25 \pm 1{ }^{\circ} \mathrm{C}$ for $72 \mathrm{~h}$. Plates without essential oil/standards and plates with Tween- 80 served as a control. Percentage growth inhibition of each fungus was evaluated by the comparison of culture diameter in between poisoned and non-poisoned Petri-plates. Experiments were repeated twice in triplicates. Minimum inhibitory concentration (MIC) was calculated using PFT formula $[6,8,24]$.

\subsection{Glasshouse experiment}

\subsubsection{Phytotoxicity of essential oil emulsion}

Phytotoxicity studies were performed using fifty seedlings per pot of each target crops in earthen pots under glasshouse conditions. Seeds were sown on autoclaved soil. Different concentrations of oil emulsion $100 \mathrm{ml} /$ pot (35, $40,45,50,55,60$ and $65 \mathrm{mg} / 100 \mathrm{ml}$ ) was added in 5 days old seedlings. Each set of experiment was replicated with three pots having 50 seedlings. Phytotoxicity results were reported by the counting of survived seedlings after the termination of experiment.

\subsubsection{Preparation of fungal inoculum}

The fungal inoculum of Oci Rh-1 and PI Rh-1 was prepared on sterilized maize seeds in separate Erlenmeyer flask by inoculating seeds with three discs $(1 \mathrm{~mm})$ of 5-day-old culture, Further, flasks were, incubated at $25 \pm 2{ }^{\circ} \mathrm{C}$ for 14 days in the dark.

\subsubsection{Preparation of essential oil emulsion}

Emulsion of L. alba oil (referred as test solution in text) in water was prepared by adding $50 \mathrm{mg}$ oil in $100 \mathrm{ml}$ distilled water with $0.1 \%$ tween-80. Flasks were shaken vigorously for $2 \mathrm{~min}$. Subsequently, flasks were kept in shaker incubator for $30 \mathrm{~min}$ at $37^{\circ} \mathrm{C}$ (200 rpm) prior to use.

\subsubsection{Management of Rhizoctonia damping off}

The experiments were conducted for two consecutive years 2013 and 2014 on O. basilicum and $P$. ovata against isolated pathogenic strains, i.e., Oci Rh-1 and PI Rh-1. A total of five different treatments were put into practice as shown in Table 1.

Seedlings were raised on autoclaved soil in 14 inch earthen pots maintained under glasshouse conditions; treatments were applied as described in Table 1. Inoculated untreated, un-inoculated treated and neither treated nor inoculated pots were served as controls. All sets of experimental pots were kept at $28 \pm 3^{\circ} \mathrm{C}$ under glasshouse conditions in triplication. Wilting of the seedlings started within $24 \mathrm{~h}$ thus, data were collected per day. Experiments were terminated after 2 weeks and percentage of survived seedlings, calculated as per formula given below:

$\%$ of survived seedlings

$$
=\frac{(\text { Total seedlings }- \text { survived seedlings })}{(\text { Total seedlings })} \times 100
$$

\subsubsection{Analysis of treated soil samples through headspace technique}

Headspace technique was utilized to investigate presence of oil constituents in treated soil samples to know the longevity of essential oil components for two given reasons; (1) to know the amount of EO needed to inhibit plant pathogen per day, (2) to check oil traces in treated soil for adverse environmental consequences. Three pots were treated with oil emulsion same as our treatment and three samples from each pots were collected ( $5 \mathrm{~g}$ soil/vial) for 2 days. Further, samples were analyzed with headspace gas chromatography.

GC analysis was done by using DB- 5 capillary column (30 $\mathrm{m} \times 0.25 \mathrm{~mm}$ i.d., film thickness is $0.25 \mu \mathrm{m}$ ) on Varian CP-3800 gas chromatograph. The column oven was

Table 1 Different sets of in vivo pot treatments used for the management of $R$. solani under glasshouse

\begin{tabular}{lll}
\hline S. no. & Treatment numbers & Treatments \\
\hline 1 & Treatment 1 (T1) & Addition of $100 \mathrm{ml}$ EOE with inoculation, followed with $50 \mathrm{ml}$ EOE after $24 \mathrm{~h}$ and $48 \mathrm{~h}$ \\
2 & Treatment 2 (T2) & $100 \mathrm{ml}$ EOE prior to inoculation, followed with $50 \mathrm{ml}$ EOE after $24 \mathrm{~h}$ and $48 \mathrm{~h}$ \\
3 & Treatment 3 (T3) & $100 \mathrm{ml}$ EOE with inoculation, once \\
4 & Treatment 4 (T4) & $100 \mathrm{ml}$ EOE prior to inoculation, once \\
5 & Treatment 5 (T5) & Addition of $100 \mathrm{ml}$ EOE day after inoculation, followed with $50 \mathrm{ml} \mathrm{EOE} \mathrm{after} 48 \mathrm{~h}$ and $72 \mathrm{~h}$ \\
6 & Control 1 (C1) & Only inoculation (fungus) \\
7 & Control 2 (C2) & Only treatment with essential oil \\
8 & Control 3 (C3) & Without addition of fungus and essential oil
\end{tabular}

EOE essential oil emulsion 
programmed from 60 to $240^{\circ} \mathrm{C}$ at the rate of $3^{\circ} \mathrm{C} / \mathrm{min}$ with final hold time of $2 \mathrm{~min}$. $\mathrm{H}_{2}$ gas was used as a carrier gas at constant flow rate of $1 \mathrm{ml} / \mathrm{min}$ in the split ratio of 1:60; makeup flow $\left(\mathrm{N}_{2}\right.$ gas) at $29 \mathrm{ml} / \mathrm{min}$ flow; $\mathrm{S} / \mathrm{SL}$ injector and detector (FID) temperatures were $280^{\circ} \mathrm{C}$.

Headspace syringe $(1 \mathrm{ml})$ was utilised to draw the sample vapours from headspace vial of $20 \mathrm{ml}$ capacity. About $5 \mathrm{~g}$ each of soil samples were weight accurately and placed in three separate headspace vials. Each vial fitted with screw cap and silicone/PTFE ( $18 \mathrm{~mm} 35$ SHORE A) septum was transported to headspace heater with the help of COMBIPAL Autosampler (CTC Analytics). Syringe was kept at $135^{\circ} \mathrm{C}$ with flush time of $15 \mathrm{~s}$. Nitrogen was used to flush the syringe. Sample incubation was carried out in a heater at $130^{\circ} \mathrm{C}$ with 5 min incubation time and incubation rpm of 300 . For sample filling, plunger fill speed was $200 \mu \mathrm{l} / \mathrm{s}$ with a total of 5 fill strokes and a viscosity delay of $5 \mathrm{~s}$. Injection was done with a pre injection delay of $0.05 \mathrm{~s}$ and plunger injection speed of $500 \mu \mathrm{l} / \mathrm{s}$.

\subsection{Data analysis}

Data were analysed using SPSS-version 23 software. T test of each set of experiment was performed with 0.05 or $95 \%$ confidence interval using default settings.

\section{Results and discussion}

\subsection{Characterization of $R$. solani isolated from 0 . basilicum and $P$. ovata}

The detailed microscopic studies have shown that both isolates (Oci Rh-1 and PI Rh-1) possessed most common and peculiar features of Rhizoctonia solani like branching at right-angle, constriction at the branch point, septation in the branch hypha near its point of origin and presence of dolipore septum. Often, chains of inflated hyphae known as monolid cells and more than two nuclei per cell have also been observed [4]. Anastamosis testing with known $R$. solani tester strains revealed that all the isolates showed $\mathrm{C} 2$ reaction with $\mathrm{Chr} 3$ strain ( $R$. solani AG $4 \mathrm{HG}-\mathrm{I})$. Therefore, it was revealed that both isolates belong to $R$. solani AG 4. However, anastomosis reaction is not sufficient and of little value for the purpose of subset identification within AG-4. Therefore, internal transcribed spacer region was analyzed for further identification of 3 isolates up to sub set level.

NCBI-BLASTn of sequences, Oci Rh-1 and PI Rh-1 showed $99 \%$ similarity with $R$. solani KJ170354 and HG934415 respectively. Both sequences of rDNA ITS region of isolated pathogens were deposited in Genbank with accession number KT970787and KT970788 respectively.
Phylogenetic tree was constructed using 50 ITS sequences retrieved from NCBI Genbank. Tree suggests that the causal organism PI Rh-1 showed close genetic relatedness with $R$. solani subset AG 4HG-I while Oci Rh-1 showed genetic relatedness with subset HG-III (Fig. 1). The evolutionary history was inferred using the Neighbor-Joining method [25]. The optimal tree with the sum of branch length $=3.78713455$ is shown. The tree is drawn to scale, with branch lengths in the same units as those of the evolutionary distances used to infer the phylogenetic tree. The evolutionary distances were computed using the Maximum Composite Likelihood method and are in the units of the number of base substitutions per site. The analysis involved 52 nucleotide sequences. All positions containing gaps and missing data were eliminated. Evolutionary analyses were conducted in MEGA7 [26]. Furthermore, this is the first report of its molecular identification up to group and sub group level as $R$. solani AG 4HG-III and AG 4 HG I.

Pathogenicity test exhibited that initial symptoms developed as water soaked lesions after 1-3 days. However, typical disease symptoms appeared after 5-10 days of inoculation such as reddish brown to tan brown necrotic lesions emerged on the bottom of stem which leads into wilting. While non-inoculated plants were free from infection. The fungus was re-isolated on PDA and identified using conventional and molecular techniques fulfilled the Koch's postulate.

\subsection{Essential oil composition}

Essential oils extracted from leaves of $L$. alba were analyzed by means of GC-FID and GC/MS techniques. Essential oil contained more than 50 compounds, of which 35 compounds contributed $93.1 \%$ of total oil composition were identified (Table 2). Linalool has contributed highest proportion $(69.2 \% \pm 1.01)$ to the oil followed by 1,8 -cineole $(3.9 \% \pm 0.61),(E, E)$-2,6-dimethyl-3,5,7octatrien-2-ol (3.2 \pm 0.8$)$, germacrene $D(2.9 \% \pm 0.75)$, $\beta$-caryophyllene $(2.3 \% \pm 0.58)$, sabinene $(1 \% \pm 0.17)$ and hotrienol $(0.3 \% \pm 0.15)$. The typical citral odour of this oil was attributed due to the presence of neral $(0.7 \% \pm 0.32)$ and geranial $(0.8 \% \pm 0.4)$. To the best of our knowledge, hotrienol, (Z,Z)- and (E,E)-2,6-dimethyl-3,5,7-octatrien2-ol are being reported for the first time in Indian Lippia essential oil (Fig. 2). High hotrienol (75.9-81.7\%) in Croatian Satureja montana honey samples has been reported so far [27].

\subsection{Diffusion (volatile) assay}

Comparative antifungal activities of Lippia alba essential oil and its isolated constituent (linalool) against $R$. solani isolates have been listed (Table 3). L. alba has been 
Fig. 1 Evolutionary relationship of isolated $R$. solani

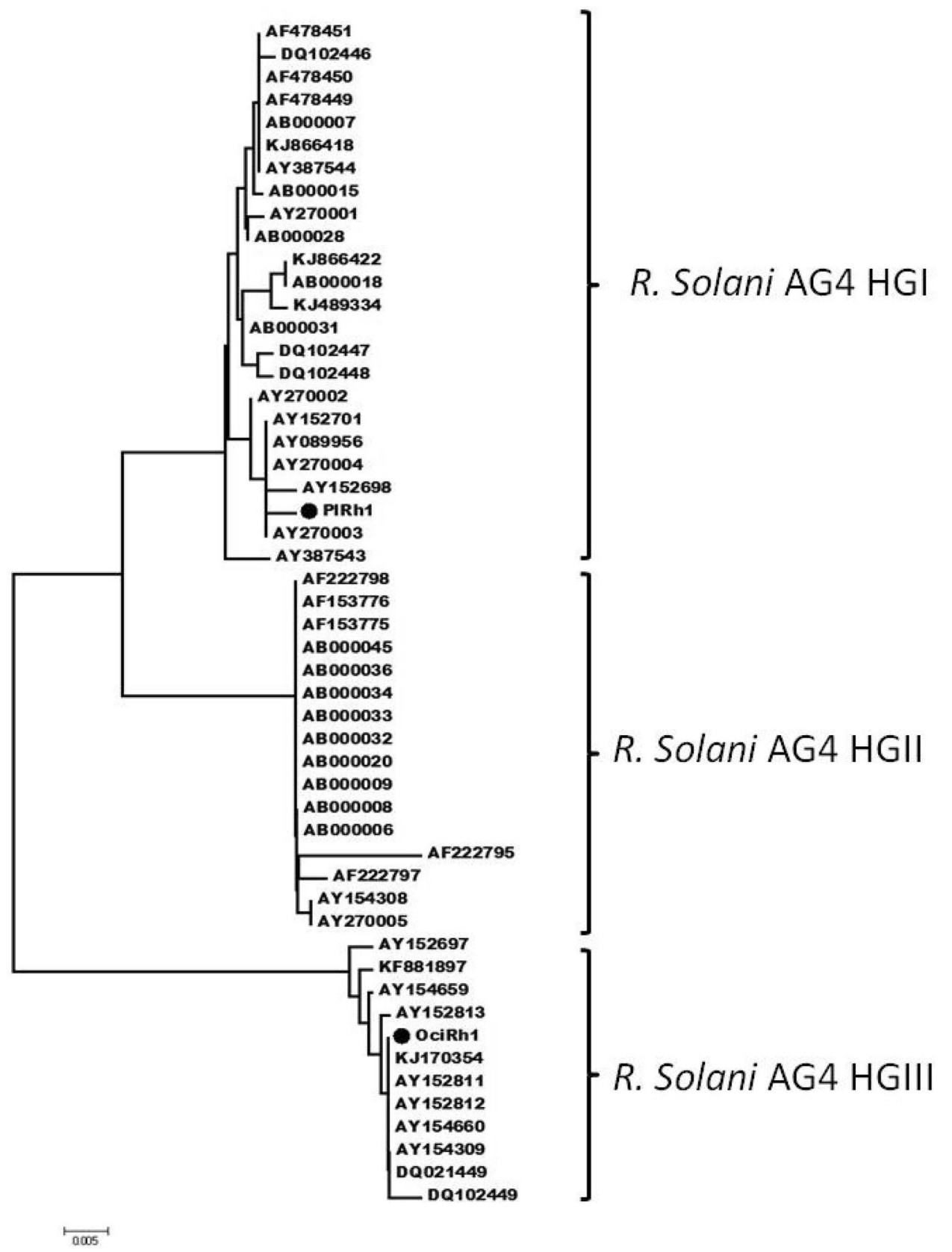

recorded as $100 \%$ and $90 \%$ whereas linalool showed $95 \%$ and $94 \%$ and $98 \%$ inhibition after 72-h against Oci Rh-1 and PI Rh- 1 isolates.

Solid-phase microextraction device fitted with $100 \mu \mathrm{m}$ PDMS fiber was utilized and revealed the presence of linalool in the Petri-plate headspace till $48 \mathrm{~h}$. Hence, we conclude that linalool imparts a major role towards activity; however, synergistic effects of remaining constituents further enhance the antiphytopathogenic nature of essential oil.

\subsection{Poison food technique (PFT)}

Antiphytopathogenic activities of L. alba essential oil and its isolate (linalool) have been listed (Table 3). L. alba has been recorded as $100 \%$ and $90 \%$ whereas linalool showed complete inhibition after $72 \mathrm{~h}$ against Oci Rh-1 and PI Rh-1 isolates, respectively.

Chemical compositions of the essential oils are very complex in nature due to the presence of different 
Table 2 Comparative proportions of constituents identified in L. alba essential oil

\begin{tabular}{|c|c|c|c|c|c|c|}
\hline \multirow[t]{2}{*}{ Compound } & \multirow[t]{2}{*}{$\mathrm{RI}$} & \multirow[t]{2}{*}{$\mathrm{Rl}_{\mathrm{a}}$} & \multicolumn{4}{|c|}{ Content \% } \\
\hline & & & Min & Max & $A v$ & SD \\
\hline \multicolumn{7}{|l|}{ Monoterpenoids } \\
\hline Sabinene & 968 & 969 & 0.8 & 1.1 & 1.0 & 0.17 \\
\hline 1-Octen-3-ol & 972 & 974 & 0.3 & 0.7 & 0.5 & 0.20 \\
\hline 6-Methyl-5-hepten-2-one & 980 & 981 & 0.2 & 0.6 & 0.4 & 0.20 \\
\hline$\beta$-Myrcene & 985 & 988 & 0.3 & 0.4 & 0.3 & 0.06 \\
\hline p-Cymene & 1019 & 1020 & $\mathrm{t}$ & 0.1 & 0.1 & 0.01 \\
\hline Limonene & 1024 & 1024 & 0.1 & 0.2 & 0.1 & 0.06 \\
\hline 1,8-Cineole & 1027 & 1024 & 3.2 & 4.3 & 3.9 & 0.61 \\
\hline (Z)- $\beta$-Ocimene & 1035 & 1032 & & 0.1 & 0.1 & 0 \\
\hline$(E)$ - $\beta$-Ocimene & 1042 & 1044 & 0.9 & 1.4 & 1.2 & 0.26 \\
\hline cis-Linalool oxide & 1068 & 1067 & 0.1 & 0.1 & 0.1 & 0 \\
\hline trans-Linalool oxide & 1084 & 1084 & 0.1 & 0.1 & 0.1 & 0 \\
\hline 3,7-Dimethyl-1,6-octadien-3-ol (Linalool) & 1102 & 1095 & 68.2 & 70.2 & 69.2 & 1.01 \\
\hline 3,7-Dimethyl-1,5,7-octatrien-3-ol (Hotrienol) ${ }^{\mathrm{a}}$ & 1103 & - & 0.3 & 0.4 & 0.3 & 0.15 \\
\hline a-Terpineol & 1186 & 1186 & 0.3 & 0.4 & 0.3 & 0.05 \\
\hline$(Z, Z)-2,6$-Dimethyl-3,5,7-octatrien-2-ol ${ }^{\mathrm{b}}$ & 1187 & - & 0.7 & 1.0 & 0.8 & 0.15 \\
\hline$(E, E)-2,6$-Dimethyl-3,5,7-octatrien-2-ol ${ }^{c}$ & 1205 & - & 2.5 & 4.1 & 3.2 & 0.80 \\
\hline Citronellol & 1225 & 1223 & 0.1 & 0.3 & 0.2 & 0.10 \\
\hline Neral & 1236 & 1235 & 0.4 & 1.0 & 0.7 & 0.32 \\
\hline Geraniol & 1251 & 1249 & 0.1 & 0.2 & 0.1 & 0.05 \\
\hline Geranial & 1265 & 1264 & 0.4 & 1.1 & 0.8 & 0.40 \\
\hline 2-Acetoxy-1,8-cineole ${ }^{d}$ & 1338 & - & 0.1 & 0.2 & 0.1 & 0.05 \\
\hline Geranyl acetate & 1380 & 1379 & 0.2 & 0.3 & 0.2 & 0.05 \\
\hline \multicolumn{7}{|l|}{ Sesquiterpenoids } \\
\hline a-Copaene & 1371 & 1374 & 0.1 & 0.1 & 0.1 & 0 \\
\hline$\beta$-Cubebene & 1385 & 1387 & 0.1 & 0.1 & 0.1 & 0 \\
\hline$\beta$-Elemene & 1388 & 1389 & 1.1 & 1.5 & 1.2 & 0.26 \\
\hline$\beta$-Caryophyllene & 1414 & & 2.6 & 2.8 & 2.3 & 0.58 \\
\hline$\beta$-Copaene & 1424 & 1430 & $\mathrm{t}$ & 0.1 & 0.1 & 0.02 \\
\hline$\gamma$-Elemene & 1429 & 1434 & 0.8 & 1.6 & 1.1 & 0.43 \\
\hline a-Humulene & 1448 & 1452 & 0.3 & 0.4 & 0.3 & 0.10 \\
\hline Aromadendrene & 1455 & 1458 & $\mathrm{t}$ & 0.1 & 0.1 & 0.02 \\
\hline Germacrene D & 1476 & 1484 & 2.5 & 3.8 & 2.9 & 0.75 \\
\hline Germacrene B & 1554 & 1559 & 0.7 & 0.9 & 0.7 & 0.20 \\
\hline (E)-Nerolidol & 1562 & 1561 & 0.2 & 0.3 & 0.2 & 0.05 \\
\hline Caryophyllene oxide & 1576 & 1582 & 0.1 & 0.3 & 0.1 & 0.11 \\
\hline \multicolumn{7}{|l|}{ Other compounds } \\
\hline Cis-3-hexenol & 846 & 850 & 0.1 & 0.3 & 0.2 & 0.10 \\
\hline Monoterpenoids & & & & & 83.7 & \\
\hline Sesquiterpenoids & & & & & 9.2 & \\
\hline Total identified constituents & & & & & 93.1 & \\
\hline
\end{tabular}

RI Retention Index on DB-5 capillary column using a homologous series of $n$-alkane $\left(C_{6}-C_{28}\right)$ hydrocarbons, Polyscience Corp. Niles IL; $\mathrm{Rl}_{\mathrm{a}}$ : Adams [38]; $\mathrm{t}:<0.1 \%$

Min minimal content, Max maximal content, Av average content, SD standard deviation

a Identification based mass spectrum and retention index [27]

$b, c$ Identification based on NMR experiments

${ }^{\mathrm{d}}$ Identified without isomer differentiation 
Fig. 2 Marker acyclic monoterpenoids identified in Lippia alba essential oil

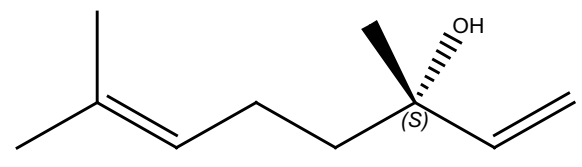

Linalool

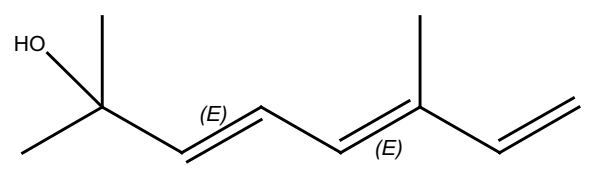

(E,E)-2,6-Dimethyl-3,5,7-octatrien-2-ol

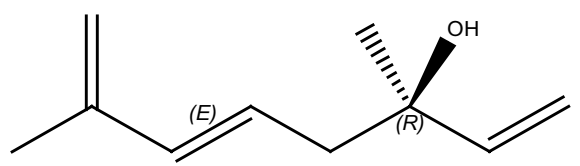

Hotrienol

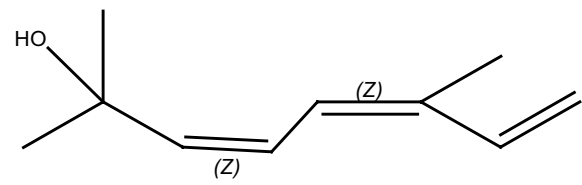

(Z,Z)-2,6-Dimethyl-3,5,7-octatrien-2-ol

Table 3 In vitro antifungal activity of $L$. alba essential oil and linalool on highly pathogenic $R$. solani isolates as per growth inhibition. Diameter of the inhibition zone represents the mean of three independent experiments

\begin{tabular}{|c|c|c|c|c|c|c|}
\hline \multirow[t]{3}{*}{ Assay type } & \multicolumn{3}{|c|}{ Oci Rh 1} & \multicolumn{3}{|l|}{ PIRh 1} \\
\hline & \multicolumn{3}{|c|}{ Observation (h) } & \multicolumn{3}{|c|}{ Observation (h) } \\
\hline & 24 & 48 & 72 & 24 & 48 & 72 \\
\hline \multicolumn{7}{|l|}{ Essential oil } \\
\hline Volatile $^{a}$ & $100(0)$ & $100(0)$ & $100(0)$ & $100(0)$ & $96(1.3)$ & $90(2.1)$ \\
\hline Contact $^{b}$ & $100(0)$ & $100(0)$ & $100(0)$ & $100(0)$ & $96(1.8)$ & $90(1.4)$ \\
\hline \multicolumn{7}{|l|}{ Linalool $^{\mathrm{C}}$} \\
\hline Volatile $^{a}$ & $100(0)$ & $98(1.4)$ & $95(1.1)$ & $100(0)$ & $100(0)$ & $94(0.7)$ \\
\hline Contact $^{\mathrm{b}}$ & $100(0)$ & $100(0)$ & $100(0)$ & $100(0)$ & $100(0)$ & $100(0)$ \\
\hline MIC value $(\mathrm{mg} / \mathrm{ml})$ & 400 & 500 & & & & \\
\hline
\end{tabular}

Standard deviation reported in parentheses

MIC minimum inhibitory concentration

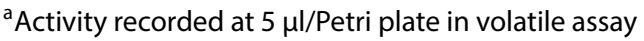

${ }^{b}$ Activity recorded at $550 \mathrm{ppm}$ in contact phase

'Isolated (purity > 95\%) from Lippia alba essential oil functional groups leading to various compound classes. Thus, it is most likely that their antimicrobial activities are not only due to a single compound or govern by one mechanism but also the presence of different targets [28]. However, the first and most important characteristic feature of oils, which plays a critical role in antagonistic activity, is hydrophobicity interaction with cell membrane. Such feature enables them to penetrate in the lipids of the cell membrane and mitochondria, disturbing the cell structure and causing cell lysis/cell bursting resulting into the leakage of ions and other cell contents $[6,22,28-30]$. Furthermore, a certain amount of leakage from cells may be abide without loss of viability while extensive loss of cell contents or critical molecules and ions will results into cell death [31]. Although studies with tea tree oil on E. coli showed that cell death may occur before lysis [29].

\subsection{Phytotoxicity of essential oil emulsion}

Phytotoxicity results revealed that seedlings treated with test solution of up to $55 \mathrm{mg} / 100 \mathrm{ml}$ concentration didn't affect the seedlings. However, slightly high dose of $60 \mathrm{mg} / 100 \mathrm{ml}$ resulted in loss, ranged from 5 to $8 \%$ seedlings. Hence, test solution of $50 \mathrm{mg} / 100 \mathrm{ml}$ was selected for further glasshouse disease management experiments. Moreover, phytotoxicity on $P$. ovata and $O$. basilicum seedlings was recorded as 60 and $65 \mathrm{mg} / 100 \mathrm{ml}$, respectively.

\subsection{Glasshouse experiment}

Disease management experiments have been carried out on $O$. basilicum and P. ovata seedlings for two consecutive years under the glasshouse conditions against isolated highly pathogenic $R$. solani -strain using L. alba 
Fig. 3 In vivo effects of essential oil against Rhizoctonia damping off in $O$. basilicum (a) and P. ovata (b) seedlings under glasshouse
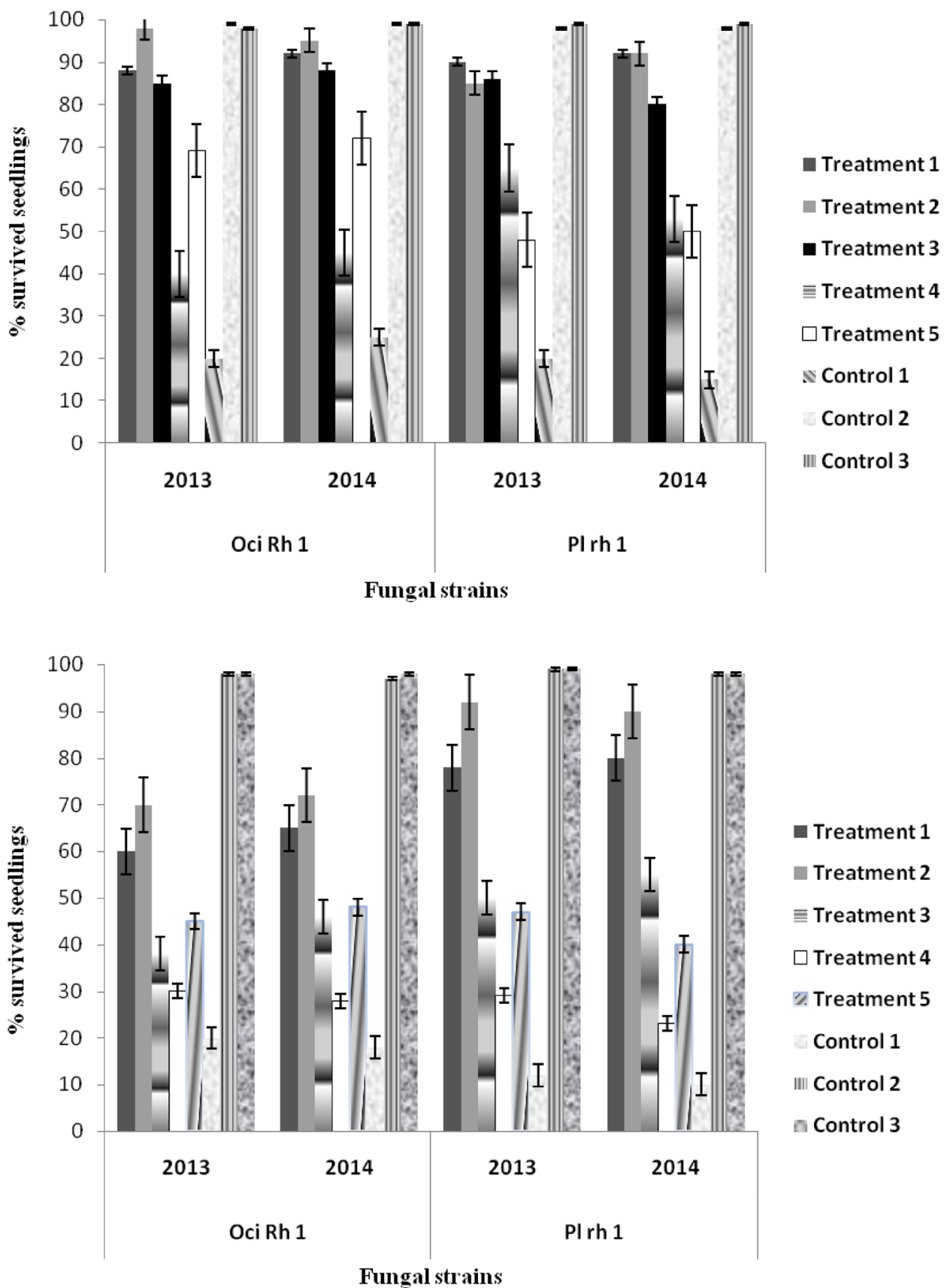

essential oil. It has been recorded that the percentage of survived seedlings were significantly different in treated and untreated pots (Fig. 3). In control 1 (inoculated + untreated), seedlings loss due to $R$. solani isolates Oci Rh-1 and PI Rh-1 was $83 \%$ and $80 \%$ (Fig. 4) for $O$. basilicum whereas $89 \%$ and $80 \%$ loss recorded for $P$. ovata plants on an average of two year experiments.

Number of survived seedlings increased in all treatments (T1-T5), compare to control 1. However, $\mathrm{T} 1$ and $\mathrm{T} 2$ showed better survival percentage of seedlings among all treatments. In T2, where essential oil was added prior to inoculation followed by two more additions of $50 \mathrm{ml}$
EOE in 24-h interval showed best results among all treatments (Fig. 4). However, in T3, essential oil was added simultaneously with inoculation also showed better survival rate than control 1. Besides, T4 and T5 did not showed significant results as compared to T1-T3 but revealed better seedlings survivability than control 1 . T-test revealed that treatment $1-3$ showing significant correlation against PI Rh1 strain in Basil as well as Plantago experiment while, T4 showed no significance. On the other hand, all treatment against Oci Rh 1 in basil showed significance. However, in plantago against Oci $\mathrm{Rh}$ 1, all treatments showed significance, except $\mathrm{T} 3$. 

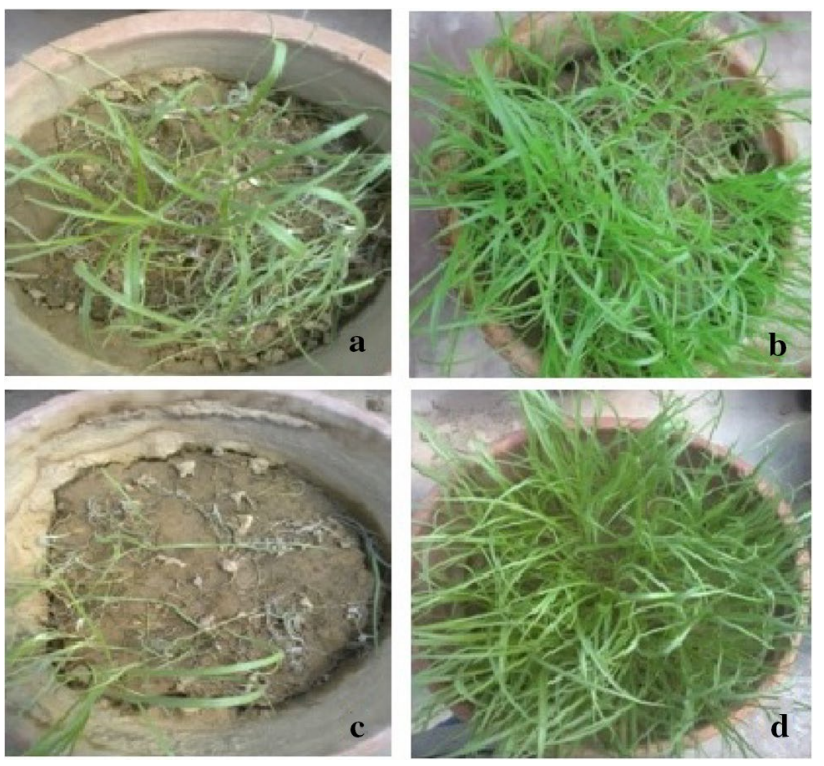

Fig. 4 Glasshouse experiment performed on P. ovata : a control 1 comprised of Oci Rh-1 isolate and $\mathbf{b}$ survived seedlings after treatment 2. c Control 1 comprised of PI Rh-1 and d survived seedlings after treatment 2

In general, oils exhibiting the strongest antimicrobial properties possessed high percentage of phenolic compounds such as carvacrol, eugenol, thymol and monoterpenes with tertiary alcohols [15, 30, 32-34]. Since, the studied Lippia alba oil contained high tertiary monoterpene alcohols (73.8\%) content. Therefore, presence of tertiary monoterpene alcohols may be correlated with strong antimicrobial action of Lippia oil against $R$. solani. In addition, it has been predicted that their mechanism of action would be similar to other phenolics; it is deemed to be the disturbance in cytoplasmic membrane, which affects proton motive force (PMF), electron flow and cytoplasm coagulation $[6,31,35]$. Chemical structure of an individual component in oils affects the precise mode of action and antibacterial activity [34]. Antagonism observed when the combined effect of compounds is less when they are together rather than applied individually. Synergism observed when combined effect is more than the sum of the individual effects [36]. However, some studies have stated that whole oils have a greater antimicrobial activity than its major component [37], hence, it also suggests that the minor components are also playing critical role in overall activity and may leads to synergistic effect.

Essential oil, which showed fungistatic activity served as better commercial option for the management of soil born plant pathogens as compared to fungicidal oils. As soil harbours natural microflora including bacteria and fungi. These microfloras are required for the plant growth promotion. If treated with fungicidal oils, it can also disturb the natural microflora of that particular area leading into poor plant growth. As already been discussed that $R$. solani affect plants at seedling stages, thus, such feature of host and $R$. solani interaction may be addressed for its management. We also found that once the plant attains certain age, then the chances to get infection from $R$. solani reduced, significantly. In such cases, management of $R$. solani in the plant nurseries through fungistatic oils are best choice and also suitable for the soil fertility.

\subsection{Headspace gas chromatography study of $L$. alba essential oil treated soil samples}

Essential oil treated soil samples under headspace gas chromatographic analysis revealed traces of oil constituents after $48 \mathrm{~h}$. Linalool, myrcene, a-copaene and $\beta$-caryophyllene were recorded in trace, however, rest of the oil constituents were found absent. Moreover, skilled use of Headspace-gas chromatography technique shall be useful to monitor the left out of various treatments in soil.

\section{Conclusion}

Current study showed potential for the development of new eco-friendly strategies to protect plants at seedling stages e.g., plant nurseries against $R$. solani infections. Management of damping off is also possible even after the onset of disease. Of the five treatments, T1 and T2 showed significant disease reduction in comparison to positive control. Many EOs have been reported with inhibitory properties against various pathogens. Most studies dealing with these compounds, however, were limited to in vitro tests. This is the first in vivo report on the activity of $L$. alba against $R$. solani isolates, globally. Since, heavy dependency on conventional chemicals in plant protection strategies led to a rising apprehension for environment among environmentalists and consumers. Therefore, natural products may be utilized as components of an integrated pest management system. The proposed strategy opens avenues for sustainable management of damping off with a final goal to reduce fungicide usage and production costs of the MAPs cultivation. Based on current plant disease management strategies, researchers may explore other oil compositions as possible biopesticides to treat similar kinds of soil borne plant pathogens like Phytophthora, Pythium, Fusarium spp. etc.

Acknowledgments The authors are grateful to the Director, CSIRCIMAP, Lucknow, India for providing research facilities, to Dr. M Alam ex-Chief scientist, Department of Plant Pathology, CSIR-CIMAP, Lucknow for his valuable suggestions; to Prof. Shiro Kuninaga, Centre for Development in Higher Education Health science University of Hokkaido, Japan for providing Rhizoctonia AG strains, to CIMAP farm 
In-charge, Lucknow for providing quality material of Lippia alba and to CSIR, New Delhi for project grant (BSC 203).

\section{Compliance with ethical standards}

Conflict of interest The authors declare that they have no conflicts of interest.

Human and animal rights No human participants and animal were involved in this study.

\section{References}

1. Agrios GN (2005) Significance of plant diseases. Plant pathology, 5 th edn. Academic Press, San Diego, pp 25-37

2. Williams JH, Phillips TD, Jolly PE, Stiles JK, Jolly CM, Aggarwal D (2004) Human aflatoxicosis in developing countries: a review of toxicology, exposure, potential health consequences, and interventions. Am J Clin Nutr 80(5):1106-1122

3. Jones RK, Belmar SB (1989) Characterization and pathogenicity of Rhizoctonia spp. isolated from rice, soybean and other crops grown in rotation with rice in Texas. Plant Dis 73:1004-1010. https://doi.org/10.1094/PD-73-1004

4. Sneh B, Burpee L, Ogoshi A (1991) Identification of Rhizoctonia species. American Phytopathological Society Press, St. Paul

5. Vilgalys R, Cubeta MA (1994) Molecular systematics and population biology of Rhizoctonia. Ann Rev Phytopathol 32:135-155. https://doi.org/10.1146/annurev.py.32.090194.001031

6. Pragadheesh VS, Saroj A, Yadav A, Chanotiya CS, Alam M, Samad A (2013) Chemical characterization and antifungal activity of Cinnamomum camphora essential oil. Ind Crops Prod 49:628633. https://doi.org/10.1016/j.indcrop.2013.06.023

7. Maia AJ, Oliveira JSB, Schwan-Estrada KRF, Faria CMR, Batista BN (2014) The control of isariopsis leaf spot and downy mildew in grapevine $\mathrm{cv}$. Isabel with the essential oil of lemon grass and the activity of defensive enzymes in response to the essential oil. Crop Prot 63:57-67

8. Saroj A, Pragadheesh VS, Palanivelu, Yadav A, Singh SC, Samad A, Negi AS, Chanotiya CS (2015) Anti-phytopathogenic activity of Syzygium cumini essential oil, hydrocarbon fractions and its novel constituents. Ind Crops Prod 74:327-335. https://doi. org/10.1016/j.indcrop.2015.04.065

9. Ma BX, Ban XQ, He JS, Huang B, Wang YW (2016) Antifungal activity of Ziziphora clinopodioides Lam. essential oil against Sclerotinia sclerotiorum on rapeseed plants (Brassica campestris L.). Crop Prot 89:289-295

10. Bahl JR, Sinha S, Naqvi AA, Bansal RP, Gupta AK, Kumar S (2002) Linalool-rich essential oil quality variants obtained from irradiated stem nodes in Lippia alba. Flavour Fragr J 17(2):127-132. https://doi.org/10.1002/ffj.1066

11. Shukla R, Kumar A, Singh P, Dubey NK (2009) Efficacy of Lippia alba (Mill.) N.E. Brown essential oil and its monoterpene aldehyde constituents against fungi isolated from some edible legume seeds and aflatoxin $B_{1}$ production. Int J Food Microbiol 135(2):165-170. https://doi.org/10.1016/j.ijfoodmicr 0.2009 .08 .002

12. Glamočlija J, Soković M, Tešević V, Linde GA, Colauto NB (2011) Chemical characterization of Lippia alba essential oil: an alternative to control green molds. Braz J Microbiol 42(4):1537-1546. https://doi.org/10.1590/S1517-838220110004000041

13. Carvalho PMM, Macêdo CAF, Ribeiro TF, Silva AA, Da Silva RER, de Morais LP, Kerntopf MR, Menezes IRA, Barbosa R (2018) Effect of the Lippia alba (Mill.) N.E. Brown essential oil and its main constituents, citral and limonene, on the tracheal smooth muscle of rats. Biotechnol Rep 17:31-34. https://doi.org/10.1016/j. btre.2017.12.002

14. Dhingra OD, Costa MLN, Silva GJ Jr, Mizubuti ESG (2004) Essential oil of mustard to control Rhizoctona solani seedling damping off and seedling blight in nursery. Fitopatol Bras 29:683-686

15. Gwinn KD, Ownley BH, Greene SE, Clark MM, Taylor CL, Springfield TN, Trently DJ, Green JF, Reed A, Hamilton SL (2010) Role of essential oils in control of Rhizoctonia damping-off in tomato with bioactive Monarda herbage. Phytopathology 100(5):493501. https://doi.org/10.1094/PHYTO-100-5-0493

16. Larkin RP (2016) Impacts of biocontrol products on Rhizoctonia disease of potato and soil microbial communities, and their persistence in soil. Crop Prot 90:96-105

17. Saroj A, Kumar A, Saeed ST, Samad A, Alam M (2013) First report of Tagetes erecta damping off caused by Ceratobasidium sp. from India. Plant Dis 97(9):1251. https://doi.org/10.1094/ PDIS-02-13-0145-PDN

18. Hyakumachi M, Priyatmojo A, Kubota M, Fukui H (2005) New anastomosis groups, AG-T and AG-U, of binucleate Rhizoctonia spp. causing root and stem rot of cut-flower and miniature roses. Phytopathology 95(7):784-792. https://doi.org/10.1094/phyto -95-0784

19. Carling DE (1996) Grouping in Rhizoctonia solani by the anastomosis reaction. In: Sneh B, Jabaji-Hare S, Neate S, Dijst G (eds) Rhizoctonia species: taxonomy, molecular biology, ecology, pathology and disease control. Kluwer Academic Publishers, Dordrecht, pp 37-47

20. Carling DE, Kuninaga S, Brainard KA (2002) Anastomosis reactions, rDNA-internal transcribed spacer, and virulence levels among subsets of Rhizoctonia solani anastomosis group 2 (AG 2) and AG BI. Phytopathology 92(1):43-50. https://doi. org/10.1094/PHYTO.2002.92.1.43

21. Kishore GK, Pande S, Harish S (2007) Evaluation of essential oils and their components for broad-spectrum antifungal activity and control of late leaf spot and crown rot diseases in peanut. Plant Dis 91:375-379. https://doi.org/10.1094/PDIS-91-4-0375

22. Knobloch K, Pauli P, Iberl B, Weigand H, Weiss N (1989) Antibacterial and antifungal properties of essential oil components. J Essent Oil Res 1(1):119-128

23. Nene $Y$, Thapliyal L (2002) Poisoned food technique of fungicides in plant disease control, 3rd edn. Oxford and IBH Publishing Company, New Delhi

24. Pragadheesh VS, Saroj A, Yadav A, Samad A, Chanotiya CS (2013) Compositions, enantiomer characterization and antifungal activity of two Ocimum essential oils. Ind Crops Prod 50:333337. https://doi.org/10.1016/j.indcrop.2013.08.009

25. Tamura K, Nei M, Kumar S (2004) Prospects for inferring very large phylogenies by using the neighbor-joining method. Proc Natl Acad Sci (USA) 101:11030-11035

26. Kumar S, Stecher G, Tamura K (2016) MEGA7: Molecular Evolutionary Genetics Analysis version 7.0 for bigger datasets. Mol Biol Evol 33(7):1870-1874

27. Jerković I, Tuberoso CIG, Marijanović Z, Kranjac M, MalenicaStaver M (2015) Antioxidant capacity and chemical profiles of Satureja montana L. Honey: hotrienol and syringyl derivatives as biomarkers. Chem Biodiv 12(7):1047-1056. https://doi. org/10.1002/cbdv.201400183

28. Skandamis PN, Nychas G-JE (2001) Effect of oregano essential oil on microbiological and physico-chemical attributes of minced meat stored in air and modified atmospheres. J Appl Microbiol 91(6):1011-1022. https://doi.org/10.104 6/j.1365-2672.2001.01467.x

29. Gustafson JE, Liew YC, Chew S, Markham JL, Bell HC, Wyllie SG, Warmington JR (1998) Effects of tea tree oil on Escherichia coli. 
Lett Appl Microbiol 26(3):194-198. https://doi.org/10.1046/ j.1472-765X.1998.00317.x

30. Lambert RJW, Skandamis PN, Coote P, Nychas GJE (2001) A study of the minimum inhibitory concentration and mode of action of oregano essential oil, thymol and carvacrol. J Appl Microbiol 91(3):453-462. https://doi.org/10.1046/j.1365-2672.2001.01428.x

31. Denyer SP, Hugo WB (1991) Mechanisms of antibacterial action-a summary. In: Denyer SP, Hugo WB (eds) Mechanisms of action of chemical biocides. Blackwell, Oxford, pp 331-334

32. Farag RS, Daw ZY, Hewedi FM, El-Baroty GSA (1989) Antimicrobial activity of some Egyptian spice essential oils. J Food Prot 52(9):665-667. https://doi.org/10.4315/0362-028X-52.9.665

33. Cosentino S, Tuberoso CIG, Pisano B, Satta M, Mascia V, Arzedi E, Palmas F (1999) In vitro antimicrobial activity and chemical composition of Sardinian Thymus essential oils. Lett Appl Microbiol 29(2):130-135

34. Dorman HJ, Deans SG (2000) Antimicrobial agents from plants: antibacterial activity of plant volatile oils. J Appl Microbiol 88(2):308-316
35. Davidson PM (1997) Chemical preservatives and natural antimicrobial compounds. In: Doyle MP, Beuchat LR, Montville TJ (eds) Food microbiology: fundamentals and frontiers. ASM, Washington, pp 520-556

36. Davidson PM, Parish ME (1989) Methods for testing the efficacy of food antimicrobials. Food Technol 43:148-155

37. Mourey A, Canillac N (2002) Anti-listeria monocytogenes activity of essential oils components of conifers. Food Control 13:289292. https://doi.org/10.1016/S0956-7135(02)00026-9

38. Adams RP (2006) Identification of essential oil components by Gas chromatography/mass spectroscopy. Allured Publishing Corp., Carol Stream

Publisher's Note Springer Nature remains neutral with regard to jurisdictional claims in published maps and institutional affiliations. 